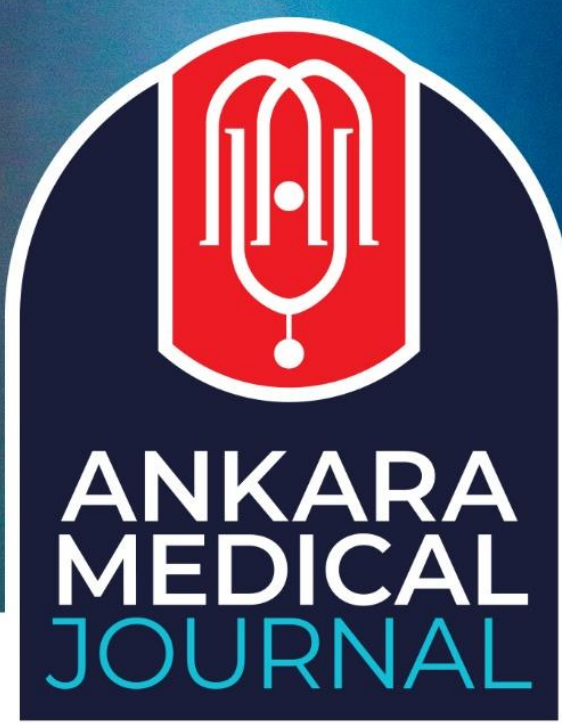

Research Article

Ankara Med J, 2020;(3):719-729 // (i) 10.5505/amj.2020.04875

\title{
EFFECTS OF UMBILICAL CORD CLAMPING TIME AFTER BIRTH ON RISK OF POSTPARTUM DEPRESSION
}

\section{DOĞUM SONRASI GÖBEK KORDONU KLEMPLEME ZAMANININ POSTPARTUM DEPRESYON RISKII ÜZERİNDEKİ ETKILERİ}

(D) Asiye Uzun ${ }^{1}$

${ }^{1}$ Medipol Üniversitesi Tıp Fakültesi, Kadın Hastalıkları ve Doğum Ana Bilim Dalı, İstanbul

Yazışma Adresi / Correspondence:

Asiye Uzun (e-mail: asiye.uzun@nisahastanesi.com)

Geliş Tarihi (Submitted): 08.07.2020 // Kabul Tarihi (Accepted): 24.08.2020

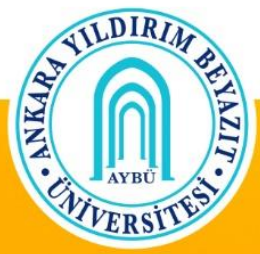

Ankara YIIdrrm Beyazıt University Faculty of Medicine Department of Family Medicine 


\section{Öz}

Amaç: Doğum sonrası göbek kordonu klempleme zamanının post partum depresyon üzerindeki etkileri değerlendirmek

Materyal ve Metot: Çalışmaya kliniğimizde 24 Ocak 2020 - 01 Nisan 2020 tarihleri arasında 36 hafta sonra doğum yapan gebeler dahil edildi. Daha önce depresyon öyküsü olanlar, kronik hastalığı olanlar, çoğul gebelikler, doğum sonrası hemodinamisi bozulmuş lohusa dönemindeki kadınlar ve doğumdan sonra Apgar skoru düşük olan veya resüsitasyon gerektiren yenidoğanlar dahil edilmedi. Postpartum göbek kordonu klempleme süresi Dünya Sağlı Örgütü'ne göre 1 dakika geç veya daha fazla ve 1 dakikadan erken olarak sinıflandırıldı. Hastalar bu gruplamaya göre iki grupta değerlendirildi. Postpartum 1. ayda yapılan takip muayenesinde poliklinikte hastalara verilen Edinburgh Doğum Sonrası Depresyon Ölçeği ile postpartum depresyon açısından riskler değerlendirildi.

Bulgular: 36 hafta üstünde olan 176 normal doğum yapan gebe çalışmaya dahil edildi. Her iki grupta sosyodemografik özellikler, obstetrik öykü ve doğum bilgileri açısından fark görülmedi. Her iki grupta ortalama

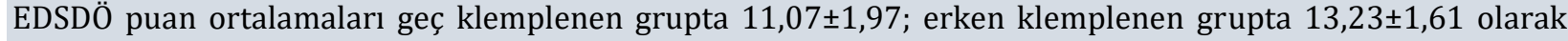
tesbit edilmiş olup istatistiki olarak anlamlı olarak bulunmuştur $(0 R=6,36 ; p<0,001)$.

Sonuç: Çalıșmamız sonucunda göbek kordonu geç klemplenen gebelerde postpartum depresyon riskinin daha az olduğunu saptadık.

Anahtar Kelimeler: Depresyon, postpartum, doğum, obstetrik, göbek kordonu.

\footnotetext{
Abstract

Objectives: To assess the effects of umbilical cord clamping time on the risk of postpartum depression.

Materials and Methods: The study included pregnant cases giving birth after 36 weeks from 24 January 2020 to 01 April 2020 in our clinic. Those with previous depression history, chronic disease, multiple pregnancies, puerperal women with impaired hemodynamics after birth, and neonates with poor Apgar score after birth or who required resuscitation were not included. The postpartum umbilical cord clamping time was classified according to the World Health Organization as of late 1 minute or more and early under 1 minute. Patients were evaluated in two groups according to this grouping. During the follow-up examination performed in the postpartum 1 month, the risks in terms of postpartum depression were evaluated with the Edinburgh Postpartum Depression Scale given to the patients in the outpatient clinic.

Results: The study included 176 pregnant cases with birth after 36 weeks. Both groups were not observed to be different in terms of sociodemographic characteristics, obstetric history, and birth information. In both groups, mean EPDS points were identified as $11.07 \pm 1.97$ in the late clamping group and $13.23 \pm 1.61$ in the early clamping group and this was statistically significant $(\mathrm{OR}=6.36 ; \mathrm{p}<0.001)$.

Conclusion: With our study results, we identified that cases with late clamping of the umbilical cord had a lower risk of postpartum depression.

Keywords: Depression, postpartum, delivery, obstetric, umbilical cord.
} 


\section{Introduction}

As a result of continuing debates about when to clamp the umbilical cord after birth, the uncertainty about a standard approach continues. The first definitions about this topic date back to the 1950s, with less than 1 minute being early and waiting more than 5 minutes accepted as late clamping. ${ }^{1-2}$

In the postpartum maternal-placental-fetal transition period, it was identified that a significant portion of the mean 70-100 mL of blood transfer to the neonate occurs in the first 1-3 minutes. ${ }^{3}$ It was identified that mean $80 \%$ of the transferred blood volume reaches healthy neonates within the first 30 seconds, so recommendations about keeping the cord clamping duration short gained popularity. However, as we approached the present day, randomized controlled studies of term and premature neonates have identified positive physiological effects on oxygenation and arterial pressure with clamping after 1-minute waiting time and a variety of debates began. ${ }^{4}$

Thus, recommendations began to turn in favor of results supporting late clamping. Late clamping was observed to provide better results for hemoglobin levels in the neonate and iron levels in the first 6 months. In fact, some studies support lower intracranial hemorrhage, lower rates of necrotizing enterocolitis, and minimized blood transfusion requirements in premature infants. ${ }^{5}$

Additionally, it should not be forgotten that the clamping time may be effective in a psychological sense as much as technically for the mother and infant. ${ }^{6}$ After the organic bond between mother and infant is broken, the continuity of the psychological bond is important for mother-baby compatibility. In this period, it is thought that skin-to-skin contact between mother and infant increases this bond.

Postpartum mental disorders occur in some mothers after birth. Postpartum problems were first defined in history in 1858 by Victor Luis Marce related to the transition to parenthood added to increasing responsibility. ${ }^{7}$ Mostly this transition is successfully overcome by many women. However, some may have moderate or mostly unnoticeable levels of mild psychiatric symptoms, while there may be severe psychosis requiring admission to the hospital at the other end of the spectrum. This psychological process is categorized under the names baby blues, postpartum depression (PPD), and postpartum psychosis. ${ }^{8}$

The incidence of postpartum depression in all societies varies according to assessments in different time periods after birth, differences in population, sampling size, and diagnostic indices. ${ }^{9}$ Though no clear factor has been identified in terms of etiology, psychological, biological, sociological, and hormonal factors have been determined. ${ }^{10}$ 
The aim of our study is to assess the effects of umbilical cord clamping time on the risk of postpartum depression.

\section{Materials and Methods}

The study included 176 pregnant cases with births after 36 weeks from 24 January 2020 to 1 April 2020. Those with a previous history of depression, chronic disease, multiple pregnancies, puerperal women with disrupted hemodynamics after birth, and neonates with poor Apgar score after birth or requiring resuscitation were not included. Pregnant women had the procedure and outcomes explained before birth and provided oral and written consent and choices were considered. The study was permitted by the Medipol University Faculty of Medicine Non-Interventional Ethics Committee on 24/01/2020 with decision number 75.

Currently, the World Health Organization (WHO) recommend that the umbilical cord be clamped a minimum of 1 minute after birth if there is no respiratory distress in healthy term and premature neonates. ${ }^{6}$ Patients were evaluated in two groups according to this grouping. In the group with late clamping, this duration ensured skin-to-skin contact while the neonate lay on the mother's lap covered by a warm blanket. All pregnant cases had sociodemographic characteristics (age, educational status, employment status, partner occupation, partner educational status, health insurance, etc.), obstetric information (age of first birth, receiving antenatal training, risk status for pregnancy, the form of birth, smoking habit), previous psychiatric diagnosis and treatment status, and anamnesis of depression in the family recorded on a maternal identification form comprising 15 questions. Mothers were assessed in terms of postpartum depression 1 month after birth using the Edinburgh Postnatal Depression Scale (EPDS).

The EPDS comprises 10 questions. Responses are assessed with a 4-point Likert scale and given points from 03. The points for each question vary, with items $3,5,6,7,8,9$, and 10 showing reducing the severity, and given points of 3, 2, 1, and 0 . However, items 1, 2, and 4 are given points of $0,1,2$, and 3 . Total points on the scale are obtained by adding item points. Those receiving 12 points or more are accepted as the risk group. The lowest points that can be obtained are 0 with the highest points of 30 . People receiving 13 points or more on the scale are accepted as at risk in terms of PPD. ${ }^{11}$ The Edinburgh Postnatal Depression Scale can be used to screen for depression from the first week after birth, and it is stated to identify $80-85 \%$ of women with postpartum depression if applied after this time. ${ }^{12}$

Our study power is 0.99 according to compare 2 Proportions: 2-Sample Equivalence with alpha 0.05. All statistical analyses were carried out using SPSS statistical software version 22.0 (IBM Corp released 2012. IBM SPSS Statistics for Windows, IBM Corp, Armonk, NY). The fit of the distribution of continuous variables was assessed with the Kolmogorov Smirnov test. Abnormal distribution was detected. Descriptive statistics are 
shown as mean and standard deviation, while nominal variables are shown as case numbers and \%. The Spearman correlation test was used to investigate the correlations between variables. Comparison of means used the independent t-test and Mann Whitney $U$ test. Results with $p<0.05$ were accepted as statistically significant.

\section{Results}

The study included 176 pregnant cases giving birth after 36 weeks of gestation. The mean age of all patients included in the study was 29.19 \pm 4.65 years (min: 20; max: 41,9). Mothers mainly comprised individuals with education at the high school level or above (n=135; 76.20\%). Of mothers, 107 (60.80\%) were housewives, and 7 (4.00\%) participants had individuals with psychiatric disease in their family. The income level in both groups was low for 40 individuals (45.50\%).

The duration for umbilical cord clamping after birth was classified according to the WHO as early clamping in less than 1 minute (Group 1) and late clamping after 1 minute (Group 2). Comparisons of study groups and pregnant cases in terms of sociodemographic characteristics are given in Table 1 and no difference was identified between the two groups.

Assessment of the correlation between the obstetric history and birth information with the study groups is given in Table 2, with no difference between the groups.

In both groups, the EPDS was applied at the check-up examination 1 month postpartum. Participants in the study had mean EPDS points of 12.15 \pm 2.01 (min:6; max:17). There were 90 participants with values of 13 and above (51.10\%) and these were assessed as at risk in terms of PPD. The correlation between those with PPD risk with sociodemographic and obstetric history and birth information is shown in Table 3 and no significant correlation was found.

The mean EPDS points of participants were identified as $11.07 \pm 1.97$ in the late clamping group and $13.23 \pm 1.61$ in the early clamping group and this was found to be statistically significant ( $\mathrm{p}<0.001$ ). Of those with PPD risk, 72.70\% (n=64) were in Group 1 and 29.50\% (n=26) were in Group 2 (Graph 1). Regression analysis was performed between the risk of PPD and clamping time. In the model, individuals with early clamping were found to have a significantly greater risk of $P P D(O R=6.36 ; p<0.001)$. 
Table 1. Assessment of sociodemographic characteristics between groups

\begin{tabular}{|c|c|c|c|}
\hline Variables & $\begin{array}{c}\text { Group } 1 \text { (Early } \\
\text { clamping; } n=88) \\
n(\%)\end{array}$ & $\begin{array}{c}\text { Group } 2 \text { (Late } \\
\text { clamping; } n=88) \\
n(\%)\end{array}$ & $P$ value \\
\hline $\begin{array}{l}\text { Age } \\
<25 \\
25-29 \\
30-34 \\
>35 \\
\end{array}$ & $\begin{array}{l}16(18.20) \\
38(43.20) \\
24(27.30) \\
10(11.40)\end{array}$ & $\begin{array}{l}21(23.90) \\
26(29.50) \\
22(25.00) \\
19(21.60)\end{array}$ & 0.407 \\
\hline $\begin{array}{l}\text { Maternal occupation } \\
\text { Housewife } \\
\text { Civil servant } \\
\text { Laborer } \\
\text { Self-employed } \\
\text { Other }\end{array}$ & $\begin{aligned} 47 & (53.40) \\
10 & (11.40) \\
10 & (11.40) \\
4 & (4.50) \\
17 & (19.30)\end{aligned}$ & $\begin{array}{r}60(68.20) \\
5(5.70) \\
8(9.10) \\
1(1.10) \\
14(15.90)\end{array}$ & 0.146 \\
\hline $\begin{array}{l}\text { Maternal education level } \\
\text { Primary school } \\
\text { Middle school } \\
\text { High school } \\
\text { University }\end{array}$ & $\begin{array}{l}10(11.30) \\
11(12.50) \\
21(23.90) \\
46(52.30)\end{array}$ & $\begin{array}{c}7(7.90) \\
13(14.80) \\
29(33.00) \\
39(44.30)\end{array}$ & 0.826 \\
\hline $\begin{array}{l}\text { Income level } \\
\text { Low } \\
\text { Moderate } \\
\text { High }\end{array}$ & $\begin{array}{l}40(45.50) \\
23(21.10) \\
25(28.40)\end{array}$ & $\begin{array}{l}40(45.50) \\
26(29.50) \\
22(25.00)\end{array}$ & 0.887 \\
\hline $\begin{array}{l}\text { Does anyone in the family have a } \\
\text { psychiatric disorder? } \\
\text { Yes } \\
\text { No }\end{array}$ & $\begin{array}{c}5(5.70) \\
83(94.30)\end{array}$ & $\begin{array}{c}2(2.30) \\
86(97.70)\end{array}$ & 0.250 \\
\hline
\end{tabular}

Table 2. Assessment of obstetric history and birth information

\begin{tabular}{|l|c|c|c|}
\hline Variables & $\begin{array}{c}\text { Group 1 (Early } \\
\text { clamping) } \\
\text { n (\%) }\end{array}$ & $\begin{array}{c}\text { Group 2 (Late clamping) } \\
\text { n (\%) }\end{array}$ & P value \\
\hline Age of first birth & $42(47.70)$ & $48(54.50)$ & 1.000 \\
$<25$ & $33(37.50)$ & $25(28.40)$ & $10(11.40)$ \\
$25-29$ & $12(13.60)$ & $5(5.70)$ & 0.172 \\
$30-34$ & $1(1.10)$ & $61(69.30)$ & $27(30.70)$ \\
$>35$ & $69(78.40)$ & $7(8.00)$ & 0.602 \\
\hline Planned pregnancy & $19(21.60)$ & $81(92)$ & \\
1-Planned & $9(10.20)$ & $41(47.10)$ & 0.603 \\
2-Unplanned & $79(89.8)$ & $46(52.90)$ & \\
\hline Did you receive prenatal care? & $38(43.20)$ & & \\
1-Yes & $50(56.80)$ & & \\
2-No & & & \\
\hline Form of birth & & & \\
1-Normal birth & & & \\
2-Cesarean & & & \\
\hline
\end{tabular}


Table 3. Comparison of PPD risk status with sociodemographic characteristics and obstetric information

\begin{tabular}{|c|c|c|c|}
\hline & $\begin{array}{l}\text { Individuals without } \\
\text { risk for PPD }(n=86)\end{array}$ & $\begin{array}{c}\text { Individuals at risk } \\
\text { of PPD }(n=90)\end{array}$ & P-value \\
\hline Age (Mean \pm SD) & $29.42 \pm 4.78$ & $28.98 \pm 4.54$ & 0.532 \\
\hline $\begin{array}{l}\text { Maternal occupation [n(\%)] } \\
\text { Housewife } \\
\text { Civil servant } \\
\text { Laborer } \\
\text { Self-employed } \\
\text { Other }\end{array}$ & $\begin{array}{l}50(58.10 \%) \\
9(10.50 \%) \\
9(10.50 \%) \\
3(3.50 \%) \\
15(17.40 \%)\end{array}$ & $\begin{array}{l}57(63.30 \%) \\
6(6.70 \%) \\
9(10.00 \%) \\
2(2.20 \%) \\
16(17.80 \%) \\
\end{array}$ & 0.760 \\
\hline $\begin{array}{l}\text { Maternal education level [n(\%)] } \\
\text { Literate } \\
\text { Primary school } \\
\text { Middle school } \\
\text { High school } \\
\text { University }\end{array}$ & $\begin{array}{c}1(1.20 \%) \\
7(8.10 \%) \\
15(17.40 \%) \\
22(25.60 \%) \\
41(47.70 \%)\end{array}$ & $\begin{array}{c}1(1.10 \%) \\
8(8.90 \%) \\
9(10.00 \%) \\
28(31.10 \%) \\
44(48.90 \%)\end{array}$ & 0.637 \\
\hline $\begin{array}{l}\text { Income level }[\mathbf{n}(\%)] \\
\text { Low } \\
\text { Moderate } \\
\text { High }\end{array}$ & $\begin{array}{l}40(46.50 \%) \\
24(27.90 \%) \\
22(25.60 \%)\end{array}$ & $\begin{array}{l}40(44.40 \%) \\
25(27.80 \%) \\
25(27.80 \%)\end{array}$ & 0.735 \\
\hline $\begin{array}{l}\text { Does anyone in the family have a } \\
\text { psychiatric disorder? [n(\%)] } \\
\text { 1-Yes } \\
\text { 2-No }\end{array}$ & $\begin{array}{lr}1 & (1.20 \%) \\
85 & (98.80 \%) \\
\end{array}$ & $\begin{array}{lc}0 & (0.00 \%) \\
90 & (100 \%) \\
\end{array}$ & 0.746 \\
\hline $\begin{array}{l}\text { Planned pregnancy [n(\%)] } \\
\text { 1-Planned } \\
\text { 2-Unplanned }\end{array}$ & $\begin{array}{l}60(69.80 \%) \\
26(30.20 \%)\end{array}$ & $\begin{array}{l}70(77.80 \%) \\
20(22.20 \%)\end{array}$ & 0.229 \\
\hline $\begin{array}{l}\text { Did you receive prenatal care? } \\
\text { [n(\%)] } \\
\text { 1-Yes } \\
\text { 2-No }\end{array}$ & $\begin{aligned} 7 & (8.10 \%) \\
79 & (91.90 \%)\end{aligned}$ & $\begin{array}{c}9(10.00 \%) \\
81(90.00 \%)\end{array}$ & 0.668 \\
\hline $\begin{array}{l}\text { Form of birth [n(\%)] } \\
\text { 1-Normal birth } \\
\text { 2-Cesarean }\end{array}$ & $\begin{array}{l}37(43.50 \%) \\
48(56.50 \%)\end{array}$ & $\begin{array}{l}42(46.70 \%) \\
48(53.30 \%)\end{array}$ & 0.679 \\
\hline
\end{tabular}




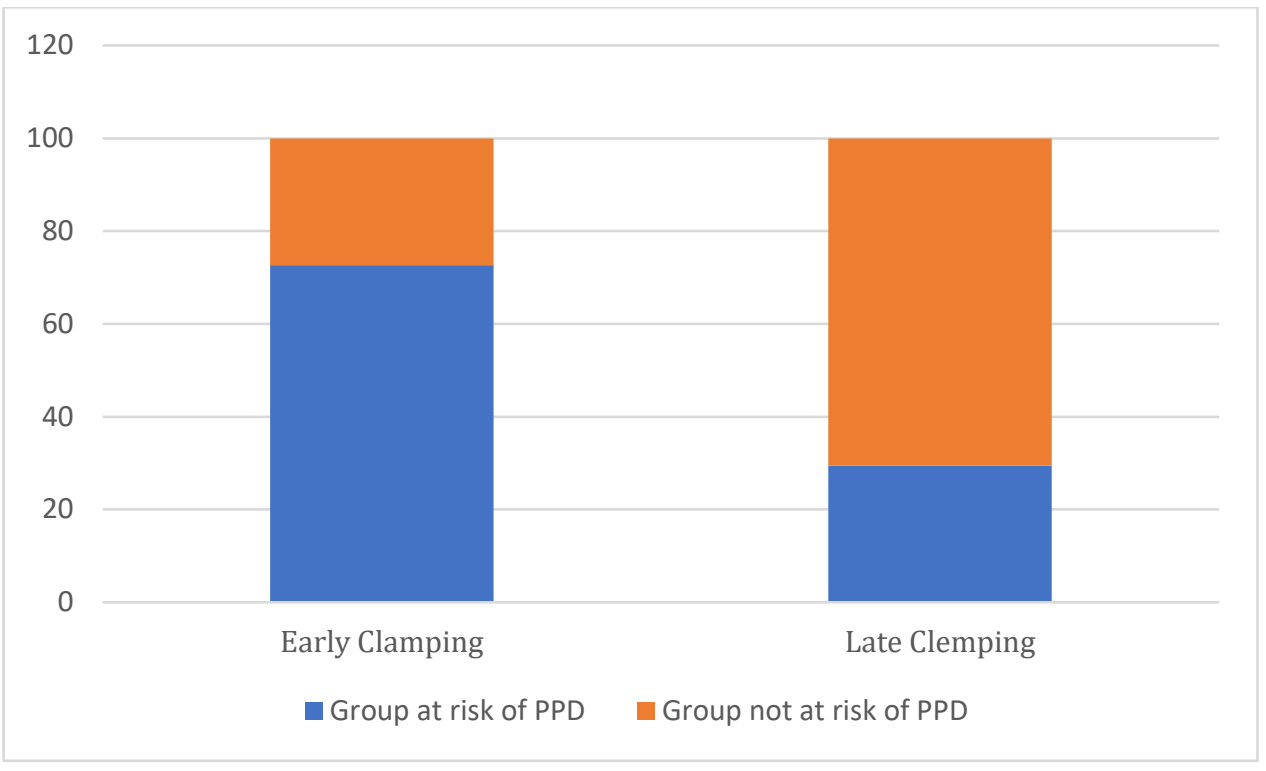

Graph 1: EPDS assessment of groups PPD risk groups

\section{Discussion}

Birth stories typically drawn as happy scenarios may take on a traumatic dimension unfortunately when combined with factors like postpartum loneliness, perception of inability to cope, lack of sufficient support from partner and other people, and social pressure. While many women adapt to the psychological changes as much as the physiological changes occurring in the process of pregnancy and after birth, some mothers may encounter these transformations with varying levels of mood disorder. ${ }^{13}$

The postpartum period begins after birth and encompasses a mean 6-week period. In mothers, changes to the body in addition to changes in psychological behavior may develop in this period. ${ }^{14}$ These changes may display as three scenarios of baby blues, postpartum depression, and postpartum psychosis. ${ }^{15}$ Hormonal changes occurring after birth may lead the individual to be more vulnerable during this process. ${ }^{16}$ As progesterone and estradiol levels which increased during pregnancy lower after birth, there may be increases in prolactin and oxytocin levels with breastfeeding. ${ }^{17}$

There are research results stating that the prevalence of postpartum depression in Turkey is between $6.00 \%$ and $58.00 \%{ }^{18}$ These rates vary around the world according to differences in depression scales used but vary from $3.50 \%-63.30 \% .{ }^{19}$ We think this broad interval is due to studies being performed in different periods and with different population characteristics. In our study, the rate for the group at risk in terms of PPD was $51.10 \%$. Though our rate is compatible with the literature, we think this incidence may have increased due to 
our study interval including the COVID pandemic. As known, an epidemic beginning at the end of December 2019 spread around the world with the first cases in our country on 11 March 2020 and the first death reported on 17 March. Up to 4 April 2020, Turkey had a total of 23,93 COVID-19 cases and the total deaths had risen to $501 .^{20}$ We think the reports that pregnant and puerperal cases are risky populations for the pandemic ${ }^{21}$, the psychological dimension of the pandemic, and the excess effects of the social isolation process on the study group may have contributed to the increased depression rates. Based on the outcomes, it will be beneficial to provide psychological support to pregnant and puerperal cases during the pandemic.

There are many studies researching the correlation between being at risk in terms of PPD and sociodemographics, obstetric history, and birth information. As the maternal education ${ }^{22}$ and employment status $^{23}$ increased, the PPD risk is supported. Another study observed statistical significance between the form of birth and planned pregnancy with PPD. ${ }^{24}$ In our study, statistical significance was not identified between the form of birth and planned pregnancy with PPD. We think this difference may be due to the structure of the sample and the effects of multiple factors.

However, the risk of PPD in the group with late clamping was identified to be significantly low compared to the group with early clamping. There are studies stating that to make late clamping more advantageous, this procedure should be performed below the placenta level with the effect of gravity, with no less transfusion identified when placed on the mother's abdomen or chest. ${ }^{25}$ In fact, this positional difference was stated to be more significant for neonates placed on the mother's chest compared to the intrauterine level. This process adds further contributions to skin-to-skin contact. ${ }^{26}$ In the group with late clamping, this waiting period was provided by placing the neonate on the mother's lap with a warm cover. We think this contact reduced the mother's risk of PPD.

In fact, postpartum depression is stated to be correlated with the quality of the first minutes of interaction between the mother and neonate. ${ }^{27}$ In the literature, one of the factors positively affecting the bonding process is stated to be ensuring skin contact in the first moments after birth and this is proposed to be the first serious step in mother and body bonding. ${ }^{28}$ Especially the mother embracing the baby while naked was identified to elevate this spell to a peak. A study identified close contact had positive effects on postpartum depression and caused higher maternal bonding points between mother and infant. ${ }^{29}$ Again, oxytocin release occurring as a result of this contact assists the mother's bond to the neonate and eases bonding. This bonding causes mothers to feel surer of themselves and creates a more tranquil environment for the infant. ${ }^{30}$

In our study, the rate of risk in terms of PPD was identified as $51.10 \%$. There were no correlations found in terms of being at risk of PPD with sociodemographic and obstetric history and birth information. Additionally, in our study, the group with late clamping had a significantly lower risk of PPD identified compared to the 
group with early clamping. We think the reason for this is that contact was ensured between mother and neonate during this waiting period. However, studies with larger groups on a duration basis, without classifying durations as early and late, will reveal this effect more clearly.

\section{Limitations}

The research reflects the population of the hospital; it should not be generalized to society.

\section{Financial Disclosure}

The authors declared that this study received no financial support.

\section{Conflict of Interest}

No conflict of interest was declared by the authors. 


\section{References}

1. Yao AC, Moinian M, Lind J. Distribution of blood between infant and placenta after birth. Lancet 1969;2:871-3.

2. Linderkamp O. Placental transfusion: determinants and effects. Clin Perinatol 1982;9:559-92.

3. Philip AG, Saigal S. When should we clamp the umbilical cord? Neoreviews 2004;5:142-54.

4. Rabe H, Diaz-Rossello JL, Duley L, Dowswell T. Effect of timing of umbilical cord clamping and other strategies to influence placental transfusion at preterm birth on maternal and infant outcomes. Cochrane Database of Systematic Reviews 2012, Issue 8. Art. No: CD003248 (doi:10.1002/14651858.CD003248).

5. McDonald SJ, Middleton P, Dowswell T, Morris PS. Effect of timing of umbilical cord clamping of term infants on maternal and neonatal outcomes. Cochrane Database of Systematic Reviews 2013, Issue 7. Art. No: CD004074 (doi:10.1002/14651858.CD004074).

6. Kluckow M, Hooper SB. Using physiology to guide time to cord clamping. Seminars in Fetal \& Neonatal Medicine 2015;20:225-31.

7. Gereklioğlu Ç, Poçan AG, Başhan İ. Postpartum psychiatric problems of mothers: review. Turkiye Klinikleri J Gynecol Obst 2007;17:126-33.

8. O'Hara MW, Zekoski EM, Philipps LH, Wright EJ. Controlled prospective study of postpartum mood disorders: comparison of childbearing and nonchildbearing women. J Abnorm Psychol 1990;99:3-15.

9. Nicolson P. Understanding postnatal depression: A mother-centred approach. J Adv Nurs 1990;15:689-95.

10. Karamustafalıŏlu N, Tomruk N. Postpartum blue and depression. Mood Disorders Series 2000;1:6471.

11. Engindeniz N. Edinburgh Doğum Sonrası Depresyon Ölçeği'nin Türkçe Formu için Geçerlilik ve Güvenirlilik Çalışması. Yüksek Lisans Tezi, Ege Üniversitesi. Psikiyatri AD, İzmir,1996, 51-52

12. Cox JL, Holden JM, Sagovsky R. Detection of postnatal depression. Development of the 10-item Edinburgh Postnatal Depression Scale. Br J Psychiatry 1987;150:782-6.

13. Collins NL, Dunkel-Schetter C, Lobel M, Scrimshaw SC. Social support in pregnancy: psychosocial correlates of birth outcomes and postpartum depression. J Pers Soc Psychol 1993;65:1243-58.

14. Gotlib IH, Whiffen VE, Wallace PM, Mount JH. Prospective investigation of postpartum depression: factors involved in onset and recovery. J Abnorm Psychol 1991;100:122-32.

15. WHO. Literature review of risk factors and interventions on Postpartum Depression, Maternal Mental Health \& Child Health And Development. Department Of Mental Health And Substance Abuse, 2008b.

16. Wilson WH, Lowdermilk P. Support for postpartum depression. Maternal Child Nursing Care. 3. ed., USA, Mosby Elsevier, 2006, 676-5.

17. Green AD, Barr AM, Galea LAM. Role of estradiol withdrawal in 'anhedonic' sucrose consumption: $A$ model of postpartum depression. Physiology and Behavior. 2009;97:259-65.

18. Arslantaş H, Ergin F, Balkaya NA. Postpartum depression prevalence and related risk factors in Aydın province. ADÜ Tıp Fakültesi Dergisi 2009;10:13-22.

19. Coşkun TD, AydınS, Çatak B. Do social determinants of health affect postpartum depression?. TAF Prev Med Bull 2016;15:414-20.

20. T.C. Saglik Bakanligi. Turkiye'deki guncel durum. 2020. Available at: https://covid19.saglik.gov.tr/ (Accessed 31 March 2020)

21. Dashraath P, Jing Lin Jeslyn W, Mei Xian Karen L, et al. Coronavirus Disease 2019 (COVID-19) Pandemic and Pregnancy. Am J Obstet Gynecol 2020; 0 (00) S0002-9378(20)30343-4.

22. Babacan Gümüş A, Keskin G, Alp N, Özyar S, et al. The prevalence of Postpartum Depression and Associated Variables. Yeni Symposium 2012;50:145-54.

23. Yılmaz Bingöl T, Tel H. Perceived social support, postpartum depression and the effecting factors in women in the postpartum period. Atatürk Üniversitesi Hemşirelik Yüksekokulu Dergisi 2007;10:1-6.

24. Taşdemir S, Kaplan S, Bahar A. Determination of the affecting factors of postpartum depression. Firat Sağllk Hizmetleri Dergisi 2006;1:105-18. 
25. Yao AC, Hirvensalo M, Lind J. Placental transfusion-rate and uterine contraction. Lancet 1968;1:3803.

26. Vain NE, Satragno DS, Gorenstein AN, et al. Effect of gravity on volume of placental transfusion:a multicentre,randomised, non-inferiority trial. Lancet 2014;453: 235-40.

27. Borghini A. Mother's attachment representations of their premature infant at 6 and 18 months after birth. Infant Mental Health Journal 2006;27:494-508.

28. Nimbalkar S, Patel V, Patel D, Nimbalkar A, Sethi A, Phatak A. Effect of earlyskin-to-skin contact following normal delivery on incidence of hypothermia in neonates more than $1800 \mathrm{~g}$ : randomized control trial. J Perinatol 2014;34:364-88.

29. Sosyal AȘ, Bodur Ş, İșeri E, Şenaol S. Attachment process in infancy: A review. Klinik Psikiyatri 2005;8:88-99.

30. Ahn HY, Lee J, Shin HJ. Kangaroo care on premature infant growth and maternal attachment and post-partum depression in South Korea. J Trop Pediatr 2010;56:342-4. 